The Development Lectora Inspire Based Learning Media for High School Students in Learning History

\title{
BUDI PURNOMO*
}

\begin{abstract}
This research aimed to develop Lectora Inspire App for history learning in high schools. Purposely, the stages of the development in using the ADDIE model which include the steps of analysis, design, development, implementation, and evaluation. Interview and questionnaires were administered in order to collect data. The interview data were analyzed qualitatively while the questionnaires were analyzed quantitatively. There were 35 respondents from one of the high schools in Jambi who were grouped into three groups, namely 3 students for a small individual group, 10 students for a small group, and 22 students for a large group. The results of this development research revealed that Lectora Inspire App based on history learning was valid based on the assessment of material experts and media experts. Moreover, based on the results of small group trials, limited group trials, and large group trials, it showed that Lectora Inspire App were effective as history learning media. Recommendations are also discussed for future research and practices.
\end{abstract}

\section{Keywords}

Development, history learning, learning media, Lectora Inspire

\footnotetext{
*Associate Professor, Faculty of Teacher Training and Education, Universitas Jambi, Indonesia; budipurnomo@unja.ac.id
} 


\section{IRJE | Indonesian Research Journal in Education | | Vol. 5 | No. 2| Dec |Year 2021|}

\section{Introduction}

The goal of education is to prepare students with guidance, teaching, or training for their future roles as a conscious effort. One of the efforts in improving the quality of education is to implement a particular curriculum that refers to the goals of national education, as stated in Law No. 20 of 2003 reads, "National education aims to develop the potential of students so that they become human beings who believe and fear God Almighty, have a noble character, are healthy, knowledgeable, competent, creative, independent, and become democratic, and responsible citizens." Moreover, there are two essential elements in learning process, namely teaching methods and learning media. One of the main functions of instructional media is teaching aid that contributes to the climate, conditions, and learning environments organized and developed by the teachers. The use of instructional media in the teaching and learning processes is able to generate new aspirations and interests; to motivate and stimulate learning activities; and even to bring psychological influences for the students. The use of instructional media through learning orientation stage will significantly assist the effectiveness of learning process and the delivery of messages and learning contents at that time (Arsyad, 2015). Furthermore, the effectiveness of the learning process is very much determined by the teaching methods and learning media used since the media consist of teaching aids designed by the teacher. Also, learning media are integral parts of learning. The use of learning media is a creative and systematic effort to create experiences that are helpful for the students, so that, in the end, the quality of graduates are determined. The optimal use of learning media needs to be based on the meaning and added value that students can provide through a learning experience. In several instances, the media are capable to reduce the limitations and shortcomings of educators in communicating learning materials. By implementing the learning media, teachers do not need to provide excessive explanations verbally (Asyhar, 2010).

However, the internet of things-based learning is rarely done. For instance, the previous research explains that the main obstacles that teachers must face are related to the access of equipment (Sariyatun et al., 2018). Meanwhile, Suryani et al. (2018) believe that it is time for the history learning to be changed, aside from explaining the chronology of the events but also integrating it with the technology. To overcome these issues, as previously mentioned, two essential elements that need to be taken into granted are teaching methods and learning media in teaching and learning process. Somehow, the visual limitations in the material and the discussion of the content in the book are incomplete. Therefore, the assumption that the material is not unusual seems to be uninteresting. Thus, the complexity of the material to be conveyed to the students can be simplified when it is assisted by the media. Since the media are capable to represent what the teacher is unable to say through certain words or sentences. Also, the abstractness of materials can be concreted in the presence of the media (Arsyad, 2015). Moreover, the use of instructional media can help teachers to overcome the limitations in the delivery of material. Therefore, the research through the development of instructional media is needed in the education context in order to develop effective media used in schools. There are many learning media in schools; one of them is to use the Lectora inspire-based learning media. 


\section{IRJE | Indonesian Research Journal in Education | | Vol. 5 | No. 2| Dec |Year 2021|}

In line with the discussion of learning media, Ulfatuzzahara (2020) stated that learning by utilizing lectora inspire-based learning media has a positive influence on learning enthusiasm. The achievement of the effectiveness of lectora Inspire-based social learning media was shown by an increase in student learning outcomes before using Lectora Inspire-based learning media after using lectora inspire-based learning media. The focus of this research was on developing lectora inspire App for history learning in high schools. Moreover, I intended to explore the stages of the development in using the ADDIE model consisting of analysis, design, development, implementation, and evaluation during history learning.

\section{Literature Review}

\section{Learning media}

The word "media" as the plural form of medium comes from Latin which means intermediary or introduction. Media can be defined as a form and channel that can be used in the process of presenting information (AECT, 1977). Learning media are all materials included the information, tools, and texts that are systematically arranged and displayed as complete pictures of the competencies that need to be mastered by the students and used in the learning process with the aim of planning and implementation of learning (Prastowo, 2014). Moreover, Muldofar (2012) said that teaching materials are all forms of materials used to assist teachers or instructors in carrying out teaching and learning activities. As explained by Suryani and Agung (2012), media are anything that can be used to transmit messages and can stimulate thoughts, arouse enthusiasm, attention, and the will of students so that it can encourage the learning process in students. Hence, media are anything that can be used to transmit messages from sender to recipient to stimulate thoughts, feelings and interests, and attention.

\section{History learning}

According to Purwanta (2007), history is defined as a unique subject consisting of events that occurred in the past and are now missing. Academically, history lessons are responsible for educating students to understand and explain various historical phenomena being studied (Purwanta, 2007). Besides, history lessons are also tasked with instilling and developing historical awareness in students (Purwanta, 2010). Additionally, one of the lessons that is competent to create behavior changes is history learning. History is a science that includes natural knowledge, research, records, and in other words includes past human activities in unique society. History is closely related to the identity and purpose of life to be achieved, moreover many lessons from the history of the human past are taken for the present (Pranoto, 2010). The development of technology in the era of the industrial revolution 4.0 is challenging for learning history in schools and universities. The principles of modernization in learning need to be possessed by teachers in creating meaningful learning for students (Mulyasa, 2007). 


\section{IRJE | Indonesian Research Journal in Education | |Vol. 5| No. 2| Dec|Year 2021|}

In a simple term, learning history is defined as a system of teaching and learning history. Widja (1991) states history learning is a combination of learning and teaching activities in which learning about past events is closely related to the present. Furthermore, by learning history around us, we can grow historical awareness that creates a sense of love for the homeland and strengthens Indonesia's identity as a great nation and a nation that will never forget its history (Syahputra et al., 2020). It can be concluded that history subjects function as a means to develop an understanding of national identity which refers to good citizenship and fosters insight into relations between nations in the world such as social development and global community development.

\section{Lectora inspire}

Lectora inspire is conceptualized as an authorized tool software for e-learning content development developed by Trivantis Corporation. Specifically, Lectora is straightforward to be used in developing interactive learning multimedia (ILM) content. Lectora is compatible with various learning management systems. In 2000, Lectora was the first AICC certified authoring system on the market. This achievement demonstrates Lectora is credible that it deserves acceptance in the e-learning industry. Since 2000, Trivantis released a version of Lectora at the beginning of each year, which contains at least 50 new features (Mas'ud, 2012). Hence, Lectora inspire is an application program that can be used to make presentations and learning media. The power of Lectora inspire is "easy to use" very user friendly in making learning media and can make test or evaluation materials (Shalikhah, 2016). Lectora inspire provides templates used to include learning materials. There are also various images, animations, animated characters that can be directly used.

Lectora inspire application has proven to be effective and feasible to be used and applied to subjects, especially history. This is confirmed by the development of previous research using Lectora inspire. The research done by Syawaluddin et al. (2019) developed Lectora Inspire application-based learning media for social studies subjects. Based on the validity of the experts, referring to the small, limited, and broad tests, the learning media are feasible to be used in the learning process for class V students of SDN 197 Sapolohe, Bontobahari District, Bulukumba Regency. A research done by Shalikhah (2016) used this application as an interactive medium for teachers. Through the Lectora inspire application, a teacher will easily develop his/her own interactive learning media to be adapted in the environment, situation, and condition of the students. Furthermore, there are also those who provide training related to Lectora inspire development. In addition, the results of this training product in the form of the Lectora learning media application can be used by teachers in supporting activities classroom learning.

\section{Methodology}

\section{Research design, site, and participants}

This research used the $\mathrm{RnD}$ (Research and Development) method. The data were collected by doing interviews and distributing a questionnaire to the 35 eleventh grader 


\section{IRJE | Indonesian Research Journal in Education | | Vol. 5 | No. 2| Dec |Year 2021|}

students on history subjects from one of the high schools in Jambi. They were grouped into three groups consisting of individual, small, and large groups. Development is the process of translating design specifications into physical forms (Seels \& Richey, 1994). Development research is an essential industrial development model used to design new products and procedures that are systematic, evaluative, and filtered and its specific criteria are found that are effective, qualified, or with similar standards (Borg \& Gall, 1983). This study used the ADDIE model instructional design. Dick and Carrey used this model in 1978; this model is also a reference for education and training program developers (Muruganatham, 2015). This ADDIE model stands for analysis, design, develop, implementation, and evaluation. In other words, ADDIE model is a combination of all of them (Molenda, 2015). Suranto (2015) stated that the ADDIE development design model is a model in which each phase is interconnected and dynamic. The results of the formative evaluation of each phase guide the next and the result of each period is the beginning of the next phase.

Figure 1. Stages of development based on ADDIE model (Source: Branch 2009)

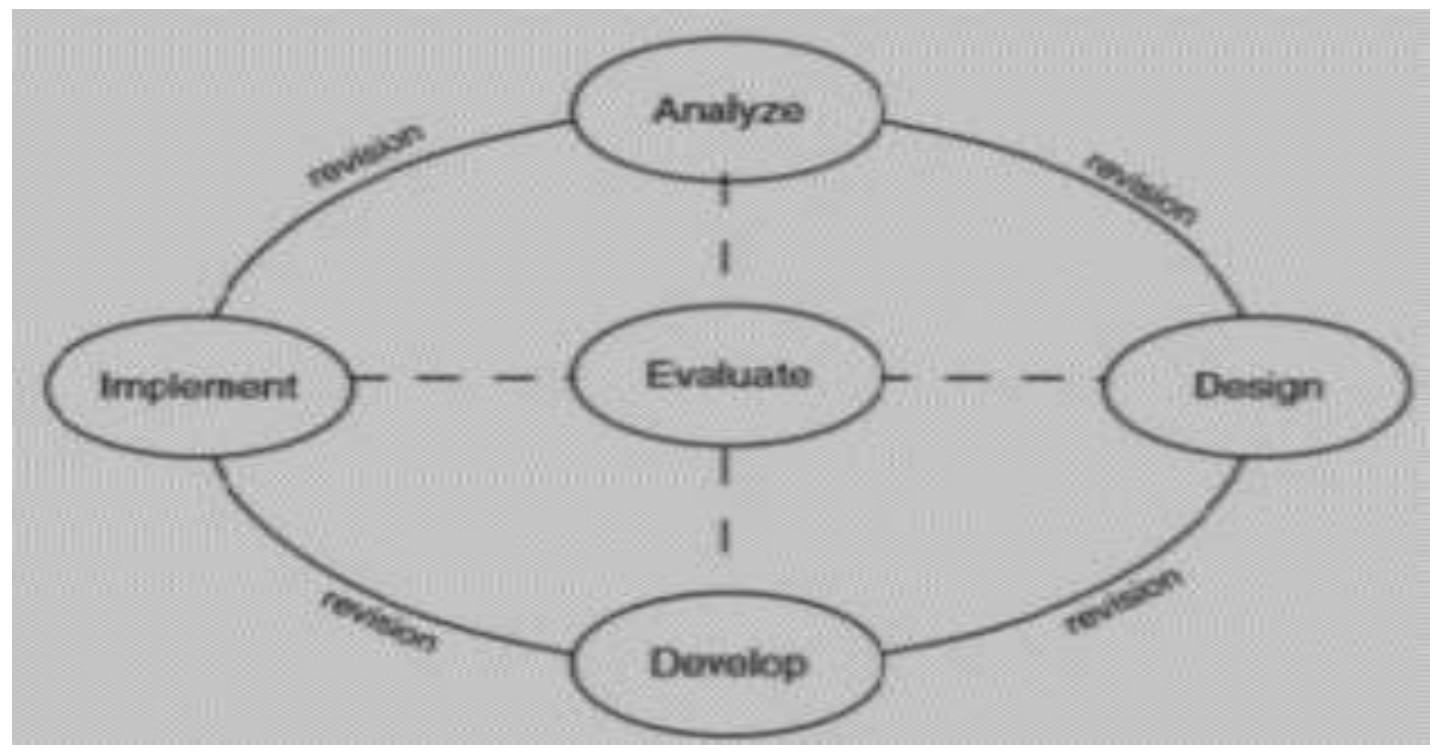

\section{Data collection and analysis}

In this development research, the types of data taken were qualitative data and quantitative data. Qualitative data were obtained from a media expert validation questionnaire equipped with a suggestion and comment column. In contrast, quantitative data were obtained from the assessment scores given by experts and student responses to Lectora inspire-based media development. This research was conducted at one of the high schools in Jambi, Jambi Province. This research was conducted upon eleventh-grader school students on history subjects. Students who are included in the test are those with different abilities. Their skills are above average, average, and under the average. 35 students participated in this research. There were 3 students for a small individual group, 10 students 


\section{IRJE | Indonesian Research Journal in Education | |Vol. 5| No. 2| Dec|Year 2021|}

for a small group, and 22 students for a large group. To determine the classification of student responses, the percentage of eligibility is used with the formula:

$$
\mathrm{K}=\frac{F}{\mathrm{~N} \times \mathrm{I} \times \mathrm{R}} \times 100 \%
$$

Information: $\mathrm{K}=$ percentage eligibility, $\mathrm{F}=$ total number of respondents' answers, $\mathrm{N}=$ highest score in the questionnaire, $\mathrm{I}=$ number of questions in the questionnaire, $\mathrm{R}=$ number of respondents. With the interpretation of the score as follows:

Table 1. Criteria for percentage of student response questionnaires (Riduwan, 2013)

\begin{tabular}{llcc}
\hline No & Score & Qualification \\
\hline 1 & 1 & $0 \%-20 \%$ & Very Deficient \\
2 & 2 & $21 \%-40 \%$ & Deficient \\
3 & 3 & $41 \%-60 \%$ & Enough \\
4 & 4 & $61 \%-80 \%$ & Good \\
5 & 5 & $81 \%-100 \%$ & Very Good \\
\hline
\end{tabular}

\section{Findings}

The results of the development of learning media based on Lectora inspire present individual, small, and large trial groups. The trial results created a product in form of learning media which can attract students' attention. There were 35 students consisting of 3 students for the individual group, 10 students for a small group and 22 students for the large group. The individual trials were carried out of three students in class XI SMA. Students included in the trial were those who have different abilities, including the students who have abilities above average, average, and below average. Small group trial data were obtained by providing a closed questionnaire containing 15 questions to the three students. In a closed questionnaire with alternative answers on a scale of numbers 1 to 5 , the data from individual trials are as follows:

Table 2. Rating scale for questionnaire

\begin{tabular}{llll}
\hline No & Scale & Score $(\mathbf{\%})$ & Qualification \\
\hline 1 & 5 & $81-100$ & Very easy / very understandable / very interesting / very precise \\
2 & 4 & $61-80$ & Easy / understand / interesting / precise \\
3 & 3 & $41-60$ & Easy enough / quite understanding / quite interesting / quite precise \\
4 & 2 & $21-40$ & Not easy / don't understand / not interesting / not right \\
5 & 1 & $0-20$ & Very not easy / very uncertain / very unattractive / very inaccurate \\
\hline
\end{tabular}

The test was carried out in class XI and the test results are presented in the following table: 
Table 3. Individual group trial

\begin{tabular}{|c|c|c|c|c|c|}
\hline \multirow[t]{2}{*}{ No } & \multirow[t]{2}{*}{ Rated Aspects } & \multicolumn{3}{|c|}{ Respondent } & \multirow{2}{*}{$\begin{array}{l}\text { Total } \\
\text { score }\end{array}$} \\
\hline & & A & B & C & \\
\hline 1 & $\begin{array}{l}\text { The presentation of the media development content presented } \\
\text { made me interested in taking history lessons. }\end{array}$ & 5 & 5 & 5 & 15 \\
\hline 2 & $\begin{array}{l}\text { The combination of writing, animation, and background displayed } \\
\text { in media development is good }\end{array}$ & 4 & 5 & 4 & 13 \\
\hline 3 & $\begin{array}{l}\text { The language used in media development is clear and easy for me } \\
\text { to understand }\end{array}$ & 5 & 5 & 4 & 14 \\
\hline 4 & $\begin{array}{l}\text { The operating instructions in media development are easy for me } \\
\text { to understand }\end{array}$ & 5 & 4 & 5 & 14 \\
\hline 5 & $\begin{array}{l}\text { The images and animations shown make it easier for me to } \\
\text { understand the concepts of the Japanese occupation in Indonesia. }\end{array}$ & 5 & 5 & 5 & 15 \\
\hline 6 & Media development using appropriate font types and sizes & 4 & 5 & 4 & 14 \\
\hline 7 & $\begin{array}{l}\text { The composition (format) of writing on each page of Lectora } \\
\text { Inspire-based media development is balanced }\end{array}$ & 5 & 4 & 4 & 12 \\
\hline 8 & $\begin{array}{l}\text { Lectora Inspire-based media development directs me to plan the } \\
\text { steps in learning activities }\end{array}$ & 5 & 4 & 4 & 12 \\
\hline 9 & $\begin{array}{l}\text { Lectora Inspire-based media development directs me to organize } \\
\text { or monitor every steps that I apply when studying }\end{array}$ & 5 & 4 & 5 & 14 \\
\hline 10 & $\begin{array}{l}\text { Lectora Inspire-based media development directs me to assess the } \\
\text { appropriateness of the methods or formulas that I use when } \\
\text { studying }\end{array}$ & 5 & 5 & 5 & 15 \\
\hline 11 & $\begin{array}{l}\text { lectora Inspire-based media development helped me to produce } \\
\text { lots of answers and have the right value in completing practice } \\
\text { questions }\end{array}$ & 4 & 5 & 4 & 12 \\
\hline 12 & $\begin{array}{l}\text { lectora Inspire-based media development helped me generate } \\
\text { various kinds of ideas with different approaches to solve practice } \\
\text { questions }\end{array}$ & 5 & 5 & 4 & 14 \\
\hline 13 & $\begin{array}{l}\text { Lectora Inspire-based media development helps me to give } \\
\text { answers that are different from the others and are correct in } \\
\text { solving practice questions }\end{array}$ & 5 & 5 & 5 & 15 \\
\hline 14 & $\begin{array}{l}\text { lectora Inspire-based media development helps me develop, add } \\
\text { and enrich an idea to clarify my answer }\end{array}$ & 5 & 4 & 4 & 12 \\
\hline 15 & $\begin{array}{l}\text { Overall, I am interested in the development of learning media } \\
\text { based on Lectora Inspire Japanese Occupation in Indonesia }\end{array}$ & 5 & 4 & 4 & 12 \\
\hline \multirow{3}{*}{\multicolumn{2}{|c|}{$\begin{array}{l}\text { Score }(\%) \text { average } \\
\text { Percentage } \\
\text { Criteria }\end{array}$}} & & & & 203 \\
\hline & & & & & $90,22 \%$ \\
\hline & & & & & $\begin{array}{l}\text { Very } \\
\text { good }\end{array}$ \\
\hline
\end{tabular}

Remarks: respondent 1: students with abilities above average, respondent 2: students with average ability, and respondent 3: students with abilities below average

Based on the results of individual trials, the table shows that three students obtained good results. The aspects that were tested received a good response from the three students. Based on the indicators, they obtained an average score of $90.22 \%$ or with outstanding criteria. Even though it obtained an average score of $90.22 \%$ or it was adjusted to the aspect table of the rating scale of "it is very easy / very understandable / very interesting / very precise", there are still some elements that need to be improved based on the comments and 


\section{IRJE | Indonesian Research Journal in Education | |Vol. 5| No. 2| Dec|Year 2021|}

opinions from the trial results. Furthermore, after the pre-test and post-test were held, the results of the scores of the three students were obtained.

Table 4. Data on the results of individual pre-test and post-test

\begin{tabular}{llllll}
\hline No & Name & Pre-test score & Mark & Post-test score & Info \\
\hline $\mathbf{1} \quad$ AYP & 72 & $\mathrm{~B}$ & 80 & $\mathrm{~A}$ \\
$\mathbf{2}$ & $\mathrm{AF}$ & 60 & $\mathrm{C}$ & 75 & $\mathrm{~B}+$ \\
$\mathbf{3} \quad \mathrm{BR}$ & 58 & $\mathrm{D}$ & 68 & $\mathrm{C}+$ \\
\hline Total & 190 & & 223 & \\
Average & 63,33 & & 74,33 & \\
\hline
\end{tabular}

Based on table 4, it shows the value of the results of individual trials and the level of understanding of the average students which obtained an average value of 63.33 and increased to 74.33 .

\section{Small group trials}

After conducting individual group trials, the next stage was small group trials. The total numbers were 10 students classified as those with above average, average, and below average abilities. The following is the result of the small group trial data.

Table 5. Individual group trial result

\begin{tabular}{|c|c|c|c|c|c|c|c|c|c|c|c|c|}
\hline \multirow[t]{2}{*}{ No } & \multirow[t]{2}{*}{ Assessment Aspects } & \multicolumn{10}{|c|}{ Respondents } & \multirow[t]{2}{*}{ Total } \\
\hline & & A & B & $\mathrm{C}$ & $\mathrm{D}$ & $\mathrm{E}$ & $\mathrm{F}$ & G & $\mathrm{H}$ & I & $\mathrm{J}$ & \\
\hline 1 & $\begin{array}{l}\text { The multimedia display of the pageflip 3D learning } \\
\text { presented made me interested in following the lesson. }\end{array}$ & 5 & 5 & 5 & 5 & 4 & 5 & 5 & 4 & 5 & 5 & 48 \\
\hline 2 & $\begin{array}{l}\text { The combination of writing, animation, and background } \\
\text { that is displayed in multimedia is good. }\end{array}$ & 4 & 5 & 4 & 4 & 5 & 5 & 5 & 4 & 5 & 5 & 46 \\
\hline 3 & $\begin{array}{l}\text { Multimedia learning makes it easy for me to understand } \\
\text { the concepts of the Japanese occupation in Indonesia. }\end{array}$ & 4 & 5 & 5 & 4 & 4 & 5 & 5 & 4 & 5 & 4 & 46 \\
\hline 4 & $\begin{array}{l}\text { The multimedia display design made me interested in } \\
\text { studying the Japanese occupation of Indonesia }\end{array}$ & 5 & 4 & 5 & 4 & 5 & 4 & 5 & 5 & 5 & 5 & 47 \\
\hline 5 & $\begin{array}{l}\text { The images and animations shown make it easier for me } \\
\text { to understand the concepts of the Japanese occupation } \\
\text { in Indonesia }\end{array}$ & 5 & 5 & 5 & 4 & 5 & 4 & 5 & 5 & 4 & 4 & 46 \\
\hline 6 & $\begin{array}{l}\text { The language used in multimedia is clear and easy for } \\
\text { me to understand. }\end{array}$ & 4 & 5 & 4 & 5 & 5 & 4 & 5 & 5 & 5 & 5 & 47 \\
\hline 7 & $\begin{array}{l}\text { The operating instructions in multimedia learning are } \\
\text { easy for me to understand. }\end{array}$ & 4 & 4 & 5 & 4 & 5 & 4 & 4 & 5 & 5 & 5 & 45 \\
\hline 8 & $\begin{array}{l}\text { The menus and buttons in multimedia can be used } \\
\text { easily. }\end{array}$ & 4 & 4 & 5 & 4 & 5 & 5 & 4 & 5 & 4 & 5 & 45 \\
\hline 9 & Multimedia uses font type and size & 5 & 4 & 5 & 4 & 5 & 5 & 5 & 4 & 5 & 5 & 47 \\
\hline 10 & Corresponding. & 5 & 5 & 5 & 5 & 4 & 5 & 5 & 4 & 5 & 5 & 48 \\
\hline 11 & $\begin{array}{l}\text { This multimedia learning makes history learning not } \\
\text { boring. }\end{array}$ & 4 & 5 & 4 & 4 & 5 & 4 & 5 & 4 & 5 & 5 & 45 \\
\hline 12 & $\begin{array}{l}\text { The arrangement (format) of writing on each } \\
\text { multimedia page of } 3 \mathrm{D} \text { pageflip learning is balanced. }\end{array}$ & 4 & 5 & 5 & 5 & 5 & 5 & 4 & 4 & 4 & 5 & 46 \\
\hline
\end{tabular}


Table 5. Continuation

\begin{tabular}{|c|c|c|c|c|c|c|c|c|c|c|c|c|}
\hline 13 & $\begin{array}{l}\text { Multimedia provides animation and video that are clear } \\
\text { and easy to understand. }\end{array}$ & 5 & 5 & 5 & 5 & 4 & 5 & 5 & 4 & 5 & 5 & 48 \\
\hline 14 & $\begin{array}{l}\text { This learning multimedia makes me excited and } \\
\text { enthusiastic about taking lessons from the Japanese } \\
\text { occupation in Indonesia }\end{array}$ & 4 & 4 & 5 & 4 & 5 & 4 & 5 & 5 & 4 & 4 & 44 \\
\hline 15 & $\begin{array}{l}\text { This learning multimedia made me enthusiastic and } \\
\text { challenged to work on practice questions about the } \\
\text { Japanese occupation in Indonesia }\end{array}$ & 4 & 4 & 5 & 4 & 5 & 5 & 5 & 5 & 5 & 4 & 46 \\
\hline & Total & & & & & & & & & & & 698 \\
\hline & Percentage & \multicolumn{11}{|c|}{$93,06 \%$} \\
\hline & Category & \multicolumn{11}{|c|}{ Very Good } \\
\hline
\end{tabular}

Based on the results of the small group trial table 5 shown, it can be seen that 10 students showed good results. Furthermore, after the pre-test and post-test were held, the results of the 10 students' scores were obtained, namely:

Table 6. Data on the results of individual pre-test and post-test

\begin{tabular}{llllll}
\hline No & Name & $\begin{array}{l}\text { Pre-test } \\
\text { score }\end{array}$ & Mark & $\begin{array}{l}\text { Post-test } \\
\text { score }\end{array}$ & Mark \\
\hline 1 & ASG & 100 & $\mathrm{~A}$ & 100 & $\mathrm{~A}$ \\
2 & AV & 48 & $\mathrm{E}$ & 60 & $\mathrm{C}$ \\
3 & BK & 56 & $\mathrm{D}$ & 70 & $\mathrm{~B}$ \\
4 & DH & 32 & $\mathrm{E}$ & 80 & $\mathrm{~A}$ \\
5 & ESP & 70 & $\mathrm{~B}$ & 100 & $\mathrm{~A}$ \\
6 & FIA & 49 & $\mathrm{E}$ & 70 & $\mathrm{~B}$ \\
7 & HM & 60 & $\mathrm{C}$ & 100 & $\mathrm{~A}$ \\
8 & IAP & 60 & $\mathrm{C}$ & 70 & $\mathrm{~B}$ \\
9 & JAH & 40 & $\mathrm{E}$ & 70 & $\mathrm{~B}$ \\
10 & LCA & 40 & $\mathrm{E}$ & 70 & $\mathrm{~B}$ \\
\hline \multicolumn{2}{l}{ Total } & 555 & \multicolumn{5}{l}{} \\
\hline \multicolumn{2}{l}{ Average }
\end{tabular}

\section{Field trial / large group}

After conducting small group trials, the next stage is the field trials. The number of students who involved in this field trial was 22 people. The following data are the data from field trials on development. 
Table 7. Field trial results

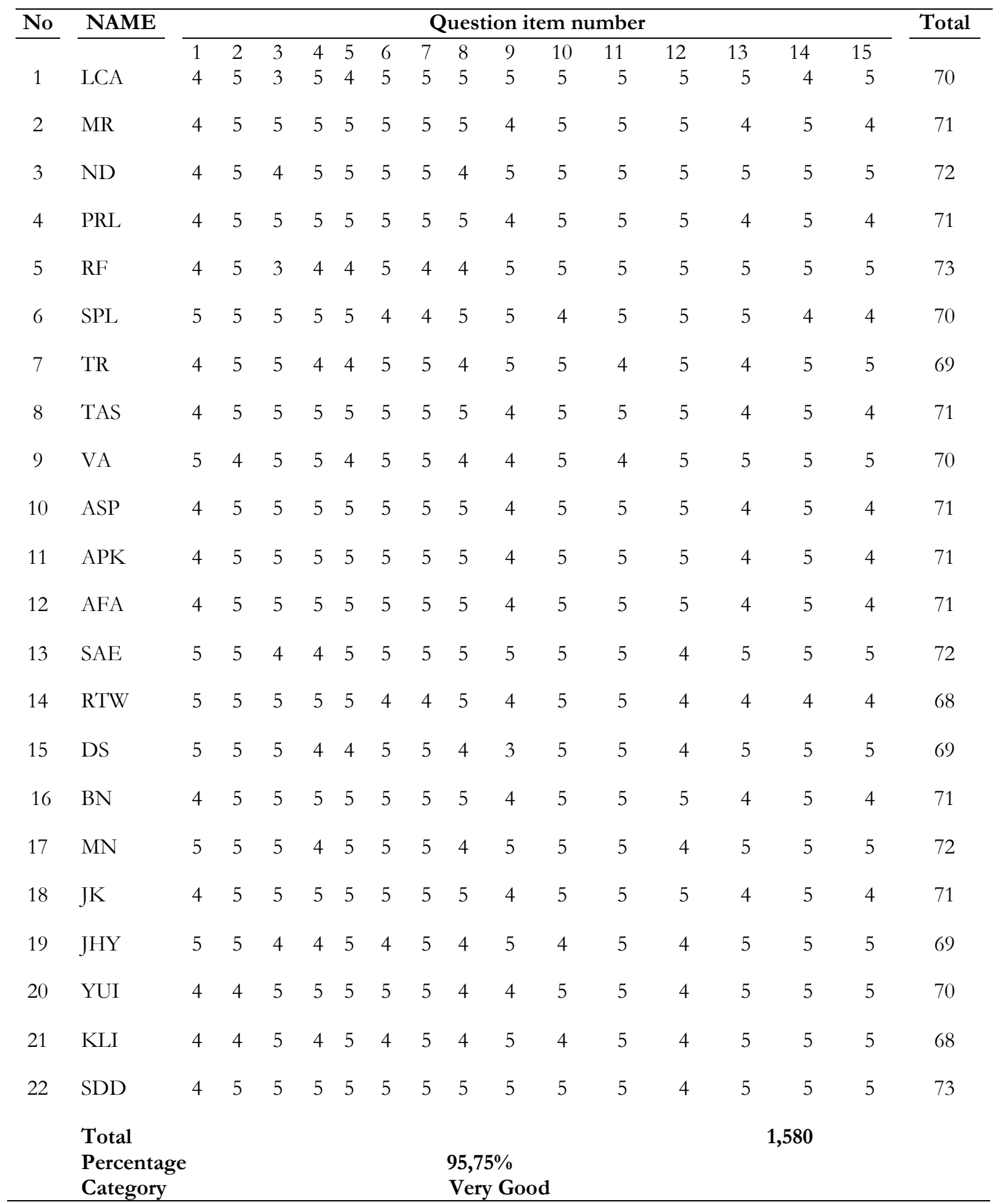




\section{IRJE | Indonesian Research Journal in Education | | Vol. 5 | No. 2| Dec |Year 2021|}

Based on the results of large group trials in table 7 , it can be seen that 22 students obtained good results. The aspects that were tested received an excellent response from 22 students based on the indicators obtained an average score of $95.75 \%$ or with excellent criteria. Furthermore, after the pre-test and post-test were held, the results obtained from the 22 students were:

Table 8. Data on the results of individual pre-test and post-test

\begin{tabular}{llllll}
\hline No & Name & $\begin{array}{l}\text { Pre-test } \\
\text { score }\end{array}$ & Mark & $\begin{array}{l}\text { Post-test } \\
\text { score }\end{array}$ & Info \\
\hline $\mathbf{1}$ & LCA & 100 & $\mathrm{~A}$ & 100 & $\mathrm{~A}$ \\
$\mathbf{2}$ & MR & 48 & $\mathrm{E}$ & 60 & $\mathrm{C}$ \\
$\mathbf{3}$ & ND & 56 & $\mathrm{D}$ & 70 & $\mathrm{~B}$ \\
$\mathbf{4}$ & PRL & 32 & $\mathrm{E}$ & 80 & $\mathrm{~A}$ \\
$\mathbf{5}$ & RF & 70 & $\mathrm{~B}$ & 100 & $\mathrm{~A}$ \\
$\mathbf{6}$ & SPL & 49 & $\mathrm{E}$ & 70 & $\mathrm{~B}$ \\
$\mathbf{7}$ & TR & 60 & $\mathrm{C}$ & 100 & $\mathrm{~A}$ \\
$\mathbf{8}$ & TAS & 60 & $\mathrm{C}$ & 70 & $\mathrm{~B}$ \\
$\mathbf{9}$ & VA & 40 & $\mathrm{E}$ & 70 & $\mathrm{~B}$ \\
$\mathbf{1 0}$ & ASP & 40 & $\mathrm{E}$ & 70 & $\mathrm{~B}$ \\
$\mathbf{1 1}$ & APK & 100 & $\mathrm{~A}$ & 100 & $\mathrm{~A}$ \\
$\mathbf{1 2}$ & AFA & 48 & $\mathrm{E}$ & 60 & $\mathrm{C}$ \\
$\mathbf{1 3}$ & SAE & 56 & $\mathrm{D}$ & 70 & $\mathrm{~B}$ \\
$\mathbf{1 4}$ & RTW & 32 & $\mathrm{E}$ & 80 & $\mathrm{~A}$ \\
$\mathbf{1 5}$ & DS & 70 & $\mathrm{~B}$ & 100 & $\mathrm{~A}$ \\
$\mathbf{1 6}$ & BN & 49 & $\mathrm{E}$ & 70 & $\mathrm{~B}$ \\
$\mathbf{1 7}$ & MN & 60 & $\mathrm{C}$ & 100 & $\mathrm{~A}$ \\
$\mathbf{1 8}$ & JK & 60 & $\mathrm{C}$ & 70 & $\mathrm{~B}$ \\
$\mathbf{1 9}$ & JHY & 40 & $\mathrm{E}$ & 70 & $\mathrm{~B}$ \\
$\mathbf{2 0}$ & YUI & 40 & $\mathrm{E}$ & 70 & $\mathrm{~B}$ \\
$\mathbf{2 1}$ & KLI & 70 & $\mathrm{~B}$ & 100 & $\mathrm{~A}$ \\
$\mathbf{2 2}$ & SDD & 49 & $\mathrm{E}$ & 70 & $\mathrm{~B}$ \\
Total & 729 & & 1750 & \\
Average & 81,23 & & 98,99 & \\
\hline
\end{tabular}

Based on table 8 , it shows the value of the results of small group trials, and it obtained data that the average level of understanding of students increased, ranging from an average of 81.23 which increased to 98.99 .

\section{Discussion}

This research aimed to develop Lectora Inspire App for history learning in high schools. At the analysis stage, needs analysis, student characteristic analysis, material analysis, objective analysis, and educational technology analysis were carried out. The design stage was carried out by making a flowchart and storyboard. The development stage was carried out by product development and assessed by a team of experts (media and material) and teacher assessments. The implementation stage was carried out in large and small group trials. The evaluation stage was carried out at each stage of the ADDIE process. 


\section{IRJE | Indonesian Research Journal in Education | |Vol. 5| No. 2| Dec|Year 2021|}

The use of ADDIE's model was described by Muruganatham (2015), who developed an e-content package that was proven to create independent learning. The e-content package is analyzed involving five phases of the ADDIE model. Mastrianto et al. (2020) developed a digital e-book of the struggles of the Lampung people which was proven to increase social solidarity, the e-book developed also used the five stages of the ADDIE model and the development of Afwan et al. (2020) who also developed a digital e-book about the struggle of the people of Lampung in Kalianda to improve students' historical empathy, as evidenced by the effectiveness of the digital flipbook learning media showing the t-test results of student learning outcomes and the t-test of historical empathy questionnaires with a significance value of $0.000<0.05$ where if the sig value is less than 0.05 , it means that the data were significant. These results indicated that there was a significant effect of using historical learning media for the digital flipbook material of the 5 Hours Battle of Kalianda on historical empathy.

Returning to the previous discussion, the data analysis of individual group trials' results got a good response from students with an average score of $90.22 \%$ or with perfect criteria. The results of the pre-test and post-test in the individual group trial showed that the average results of students had increased, where they initially obtained an average score from 63.33 to 74.33 . The next stage was the small group trial; the small group trial showed good results from 10 students with an average of 93.06 or very good. The results of the pre-test and post-test showed that the results increased significantly, ranging from the initial results of 63.33 to 83.25 .

There were 22 students who participated in the large group or field trials. The results of large group trials or in the field showed outstanding response results by obtaining an average score of 95.75 or excellent criteria. Based on the description above, it can be concluded that the use of Lectora Inspire for history learning was effective enough. As Syaifuddin (2019) explaind that the results of the effectiveness of learning media using Lectora Inspire were known to use the test formula by identifying the relationship between the control class and the experimental class. Additionally, Munfaida (2019) believes that the development of Lectora Inspire is an excellent score category overall in historical materials.

A Lectora Inspire-based development varied and is customized as possible as has been developed by Pertiwi (2018), that leads this Lectora-based learning media named "Lentera History" and validated by media and material validators by obtaining good results. The results of the pre-test and post-test also increased from $61 \%$ to $81 \%$. Lectora Inspire also has a broader impact that can improve learning in an institution, one of which is research done by Shalikhah et al. (2017), which developed Lectora Inspire to improve learning in MIM Jagalan and MIM Jumoyo, Salam District, Magelang District. It can be concluded that the increases from the research results above become a reference that this Lectora Inspire-based learning media may be useful for use in learning activities, especially on historical subjects. Moreover, Wahyuni et al. (2020) developed an interactive module using lectora inspire 18 in the history of Islamic culture at MAN 2 Tanah Datar. Moreover, Munfaida and Hermanto (2019) developed an Interactive multimediaon historical narrative text based on Lectora Inspire students in primary school.

Furthermore, Lectora Inspire is proved effective to be developed as a learning media. In previous research, Wibawa et al. (2017) showed that the percentage of the average student 


\section{IRJE | Indonesian Research Journal in Education | | Vol. 5 | No. 2| Dec |Year 2021|}

response against Lectora media inspire was $85.9 \%$. The percentage of student learning results expressed the satisfaction with the presentation of graduation of $84.375 \%$. It can be inferred that Lectora Inspire obtains good results and the media can be said to be effective as a learning tool to supporting study students. Syaifudin (2019) explained that the results of the effectiveness of learning media using Lectora Inspire were known to use the t-test formula by looking for the relationship between the control and experimental class. Of the ten respondents, it is found decent results and it can increase learning motivation. In conclusion, all of the previous studies above prove that thed media are valid and feasible for history learning both in terms of expert validation and from limited trials.

\section{Conclusion}

This development research results indicated that the Lectora Inspire-based learning media for history learning in high school students is proven valid based on the assessment of media and material experts. Based on the results of small group trials, limited group trials, and large group trials, it showed that the use of Lectora Inspire for history learning was effective enough for history learning in high school. Moreover, learning is very dependent on the methods and media used. At present, the use of technology is an inseparable part of learning history. The use of learning media is a creative effort to provide something different to students. A large number of learning media makes educators choose what media to use in learning freely. Somehow, it should be noted that in its application, educators must also develop themselves to adapt to technological developments. It is suggested that this research can actually be developed further. The limitations of the research presented here are the limitations of the research subjects which are still relatively small and can still be improved. We hope that this development can inspire and be useful for teachers in presenting interesting history lessons.

\section{Disclosure Statement}

The author declares no conflict of interest in the design of the research, in the collection, analysis, or interpretation of data, in the writing of the manuscript, or in the decision to publish the results.

\section{Acknowledgement}

We would like to acknowledge the Indonesian Research Journal in Education

(IRJE) for providing the researcher opportunity to internationally publish academic and scholarly works.

\section{References}

AECT. (1977). The definition of educational technology. Washington: Association for Educational Communication and Technology. 


\section{IRJE | Indonesian Research Journal in Education | | Vol. 5 | No. 2| Dec |Year 2021|}

Afwan, B., Suryani, N., \& Ardianto, D. T. (2020). The development of digital flipbook media based on the 5 hours battle of kalianda upon high school history materials. Budapest International Research and Critics Institute-Journal (BIRCI-Journal), 1003-1012.

Arsyad, A. (2015). Media pembelajaran. Jakarta: Rajawali Pers.

Asyhar, R. (2010). Kreatif mengembangkan media pembelajaran. Jakarta: Referensi Jakarta.

Borg W.R., \& Gall M.D. (1983). Education research an introduction. New York: Longman

Branch, R. M. (2009). Instructional design: The ADDIE Approach. NewYork: Springer.

Mastrianto, A., Sariyatun., \& Suryani, N. (2020). Development of history-based digital book based on the 19th century Lampung's people army struggle in local history lessons. Budapest International Research and Critics in Linguistics and Education (BirLE) Journal, 3(2), 809-19.

Mas'ud, M. (2012). Membuat media pembelajaran dengan lectora inspire. Yogyakarta: Skripta.

Muldofar, A. (2012). Aplikasi pengembangan kurikulum satuan tingkat guruan dan bahan ajardalam guruan Islam. Jakarta: Rajawali Pers.

Munfaida, S., \& Hermanto, H. (2019). Pengembangan multimedia interaktif pada materi teks narasi sejarah berbasis lectora inspire peserta didik kelas v SD. Doctoral dissertation. Yogyakarta: Universitas Ahmad Dahlan.

Muruganatham, G. (2015). Developing of e-content package by using ADDIE Model. International Journal of Applied Research, 1, 52-54.

Mulyasa. (2007). Menjadi guru profesional: Menciptakan pembelajaran kreatifdan menyenangkan. Bandung: Remaja Rosdakarya.

Molenda, M. (2015). In search of the elusive addie model. international society for performance improvement. Wiley Online Library. 42(4), 34-36.

Pertiwi, D. C. (2018). Pengembangan media pembelajaran sejarah berbasis lectora inspire pada materi Islamisasi di Nusantara untuk siswa kelas X di SMKN 7 Malang. Doctoral dissertation. Malang: Universitas Negeri Malang.

Pranoto, W. S. (2010). Teoridan metodologi sejarah. Yogyakarta. Graha Ilmu.

Prastowo, A. (2014). Panduan kreatif membuat bahan ajar inovatif. Yogyakarta: Diva Press

Purwanta, H. (2010). Hakekat pendidikan sejarah. Jurnal Historia Vitae, 24(1), 24-37.

Purwanta, H. (2007). Membangun kriteria rekonstruksi sejarah. Jurnal Arah Reformasi Indonesia, 34.

Riduwan. (2013). Skala pengukuran variabel-variabel penelitian. Bandung:Alfabeta

Sariyatun, Joebagio, H., \& Akhyar, M. (2018). Teachers' perception on digital teaching material development in social science education. Journal of Turkish Science Education, 15.

Seels, B., \& Richey, R.C (1994). Teknologi pembelajaran. Jakarta: Unit Penerbit Universitas Jakarta.

Shalikhah, N. D. (2017). Media pembelajaran interaktif lectora inspire sebagai inovasi pembelajaran. Warta LPM, 20(1), 9-16.

Shalikhah, N. D. (2016). Pemanfaatan aplikasi lectora inspire sebagai media pembelajaran interaktif. Cakrawala: Jurnal Studi Islam,11(1), 101-115.

Suranto. (2015).Teori belajar dan pembelajaran kontemporer. Yogyakarta: Presindo.

Suryani, N., Setiawan, A., \&Putria.A. (2018). Media pembelajaran inovatifdan pengembangannya. Bandung: Rosda 


\section{IRJE | Indonesian Research Journal in Education | | Vol. 5 | No. 2| Dec |Year 2021|}

Suryani, N. (2016).Utilization of digital media to improve the quality and attractiveness of the teaching of History. The 2 nd International Conference on Teacher Training Sebelas Maret University, 2(1).

Suryani, N., \& Agung S, L. (2012).Strategi belajar mengajar. Yogyakarta: Ombak

Syaifudin, M. A. (2019). Pengembangan media pembelajaran berbasis Lectora Inspire dalam pembelajaran ski kelas VIII di Mts. Wahid Hasyim 01 Dau. Vicratina: Jurnal Pendidikan Islam, 4(1), 18-24.

Syahputra, M. A. D., Sariyatun, S., \&Ardianto, D. T. (2020) Peranan penting sejarah lokal sebagai objek pembelajaran untuk membangun kesadaran sejarah Siswa. Historia: Jurnal Pendidik dan Peneliti Sejarah, 4(1), 85-94.

Syawaluddin, A., Makkasau, A., \& Jamal, I. F. (2019). Pengembangan media pembelajaran berbasis aplikasi Lectora Inspire pada mata pelajaran IPS kelas V di SDN 197 Sapolohe Kecamatan Bonto bahari Kabupaten Bulukumba. JIKAP PGSD: Jurnal Imiah Ilmu Kependidikan, 3(3), 294-306.

Ulfatuzzahara, T. (2020).Developing lectora inspire-based learning media on social science subjects. Harmoni Sosial: Jurnal Pendidikan IPS, 7(1), 45-53.

Wahyuni, N., Adripen, A., \& Herawati, S. (2020). Pengembangan modul interaktif dengan menggunakan lectora inspire 18 pada mata pelajaran sejarah kebudayaan Islam di Man 2 Tanah Datar. At-Tarbiyah: Jurnal Pendidikan Islam, 1(1), 25-34.

Wibawa, S. C. (2017). The design and implementation of an educational multimedia interactive operation system using Lectora Inspire. Elinvo (Electronics, Informatics, and Vocational Education), 2(1), 74-79.

Widja, I. G. (1991) Sejarah lokal suatu perspektif dalam pengajaran sejarah. Bandung: Angkasa.

\section{Biographical Note}

BUDI PURNOMO is an associate professor, Faculty of Teacher Training and Education, Universitas Jambi, Indonesia; budipurnomo@unja.ac.id 